\title{
From Islamic Teaching to Social Charity: The Muhammadiyah Movement in Semarang, Central Java, Indonesia; 1926-1940
}

\author{
Mukhamad Shokheh ${ }^{1}$, Mansoureh Ebrahimi ${ }^{2}$ \& Kamaruzaman Yusoff ${ }^{2}$ \\ ${ }^{1}$ Faculty of Islamic Civilization, Universiti Teknologi Malaysia. Lecturer at Department of History Universitas \\ Negeri Semarang (Semarang State University), Indonesia \\ ${ }^{2}$ Faculty of Islamic Civilization, Universiti Teknologi Malaysia \\ Correspondence: Corresponding author: Mansoureh Ebrahimi, Senior Lecturer at Faculty of Islamic Civilization, \\ Universiti Teknologi Malaysia.Email: mansoureh@utm.my; suriebrahimi@gmail.com
}

Received: May 22, 2018

doi:10.5539/ach.v10n2p58
Accepted: May 26, 2018

URL: http://dx.doi.org/10.5539/ach.v10n2p58

Online Published: July 16, 2018

\begin{abstract}
From the colonial period until present day, Muhammadiyah has slowly emerged as one of the largest $d a^{\prime} w a h$ organizations in Indonesia. The failure of colonial politics and the rise of religious revivalism provided a firm foundation for the movement's growth, which includes its stronghold in Semarang. Its strategic use of propaganda and its several impacts on social change obtained the movement's ascent in Semarang. The present study employs historical reviews as well as scholarly criticism and clarifications to qualitatively examine and validate the movement's establishment. From 1929 through to 1940, the authors detail the development and dissemination of Muhammadiyah's doctrines and its various charitable activities. The authors subsequently conclude that the Muhammadiyah movement has strengthened the position of Indonesian Muslims and effectively countered the influence of Christian missionaries. Thus, Muhammadiyah acts as a buffer, one that furthers the emergence of an autonomous Islamic civil society that brims with moral responsibility.
\end{abstract}

Keywords: Muhammadiyah, da'wah, Islamic teaching, social charity

\section{Introduction}

The end of the 19th century marked a milestone in the development of Islam in Indonesia. During this period, an important process birthed the "Institutionalization of the Ulama" (Burhanudin, 2007:13) characterized by the establishment of Islamic educational institutions and the emergence of a new class of socially responsible and active Muslim scholars (Nasikun, 1991). This Islamic movement brought social, political and cultural changes that formed a base from which reform movements emerged in the 20th century.

Two major factors guided the process. The first involved the transnational experience of Muslim scholars who studied in Mecca. This cadre began an evolutionary legitimizing reformation of the Ulama as a social group with valid credentials for the interpretation and dissemination of sound Islamic doctrine. This process was further strengthened by the institutionalization of the pesantren as a system of Islamic education that became increasingly widespread while, at the same time, so did the network of newly credentialed scholars. Secondly, Sufism and the practice of tarekat simultaneously resurrected alongside pesantren growth. The tarekat system had been important source of discourse for the transmission of Islam throughout the archipelago during the 19th Century (Dhofier, 1994:61).

Twentieth Century Islamic reforms in Indonesia became characterized by the offspring of the cited scholarly network and by new organizational and identitarian ideas (Kuntowijoyo, 1999:81). However, Snouck Hurgronje said that "Every new period in the history of civilization necessitates a general review of the content of its treasury" (Wertheim, 1999:161). At the beginning of the 20th century, Indonesia's Islamic countenance and renewal cannot be separated from a review of the country's Islamic treasures.

Islamic students (santris) began rebuilding defunct power structures. At the time, a santris middle class evolved a separate identity from the masses (Kuntowijoyo, 1999;101). Simulaneously, Muslim natives began realizing the need for a change in strategy in their struggle against colonial powers whose missions had managed to penetrate local traditional lifeways even without relevance (Deliar, 1996:37). Hence, a fervent desire to rehabilitate traditional Islam and reinvigorate Muslim identity and future perspectives began to crystalize. 
At the beginning of the 20th Century, urban societies were replacing village communities as initiators of change, despite increasingly complex municipal challenges. At the time, the dominant urban discourse was focused on progress. Nonetheless, along with increasing interests in Islamic reform and renewal, Muhammadiyah associations appeared in Yogyakarta, Bandung, Solo and Padang, all working to establish a robust basis for the rebirth of Islamic reforms that soon spread to other regions.

Semarang soon joined the list where its members began dynamic preaching campaigns that introduced novel ideas on organization, leadership and Islamic identity. Their efforts influenced the general movement's perspective and formulated new strategies and which established Semarang as an integral center of reform (Shokheh, 2015:147).

\section{Research Method}

Beginning with a compendium of resources, this review reconstructed the history of Muhammadiyah Islamic preaching in Semarang. Primary source documents were obtained from the Muhammadiyah central office in Yogyakarta. These included Qa'idah Moehammadijah Bahagian Penolong Kesengsaraan Oemoem (PKO) Hindia Timoer di Djokjakarta; and Berita Tahoenan Moehammadijah Hindia Timoer Tahoen (1927). From Yogyakarta's Islamic library, the authors obtained annual extracts from Soeara Moehammadijah and Hindia Timoer (newspapers). Local magazines included Swara Islam and Perhoeboengan as sources used to compare documents and manuscripts. The latter provided information on the daily lives of different social strata; albeit, drawbacks included newspaper/magazine writing styles as well as brevity, fragmentation and a general lack of continuity. Hence, the authors gained but little bits of data for specific events along with insufficient biographical sketches. To compensate, oral history was taken from people who were still able to provide an overview from colonial times through to 1940 . Thus, the data obtained reflects a collective memory of events and social conditions as well as Muhammadiyah Preaching, primarily in Semarang.

Following data collection, the next step was external and internal source criticism in which the authors began a verification process to collate documents and materials. This involved comparisons of several sources regarding facts as well as contradictions and suitability. In cases where facts were contradictory, the authors determined degrees of source reliability by referencing primary sources; thus justifying historical validity by origin. The next step was analytical interpretation whereby the authors attempted to discover and simultaneously develop cause and effect relationships that endorsed the order of occurrences taken from testimonies and documents. Facts were then linked via logical unity to produce an historical account (Shokheh, 2015:145).

This paper therefore primarily concerns the establishment, circumstances and development of the Muhammadiyah Movement (MM) in Semarang from 1926 to 1940. Of particular focus are factors that specifically encouraged its emergence in Semarang, and the group's approach to propagation as well as the MM's impact(s) on social change.

\section{Results and Discussion}

\subsection{The Growth of Muhammadiyah in Semarang}

Muhammadiyah became known as a movement with a remarkable and rapid level of expansion that reached nearly all regions of Indonesia. Founded in Yogyakarta on 18 November 1912 by KH Ahmad Dahlan, the MM sprang forth as the result of various political, cultural and religious conditions (Pasha \& Darban, 2000:61). According to Deliar Noer, the MM rose hand in hand with changes in Indonesia's Islamic struggle, philosophical orientation and intense competition with Christian missionaries and colonialism (Deliar, 1996:37). In line with this perspective, Benda perceived Muhammadiyah's establishment as a creative response to sterile formalism, stale indigenous cultural more's, the Dutch Priyayi subculture, western attitudes, and a status quo colonial mindset (Benda, 1980:72-73).

Historically, Muhammadiyah had always been known as a preaching and renewal movement that emphasized amar ma'ruf and nahi munkar, which comprise activities that invite what is good and prevent what is evil. Thus, these activities became the movement's inherent identity markers. Moreover, these same sentiments integrated the movement's preaching via literature and numerous acts of charity (Nashir, 2010:263). Muhammadiyah adherents were known for the practice of tajdid, which seeks to purify Islamic doctrine and thus bring a continuum of renewal. Within this context, the MM actively and characteristically linked Islamization in Indonesia with both tajdid and renewal (Nashir, 2010:281).

Until 1916 the movement remained limited to the Kauman area of Yogyakarta but began to spread, via preaching, in 1917. This advance is inseparable from KH Ahmad Dahlan's impressive tabligh at the Budi Utomo Congress in Yogyakarta (1917), after which the movement began receiving numerous requests to open new branches in various places throughout Java. 
Now considered an important Indonesian organization by many, the MM prepared tools of expansion. This required changes in its Articles of Association, which were revised in 1920 to expand its scope of activities throughout Java, and again in 1921 to include all of Indonesia. Since then, the MM's preaching became widespread, as well documented by the opening of new branches in several places, including Semarang.

Semarang's branch was officially established in 1926 following MM activities in Kampungs Petrus and Mijen. According to Ali Kholil, the secretariat of the MM Semarang branch began in an area presently called Jalan Kakap, No. 72 Melayu Darat, West Semarang Sub-District. The Muhammadiyah Semarang Branch (MSB) was initiated by KH Dzulqornain, Abdul Rahman Makhrus and KH Mashud Ilyas (Interview: KH Ali Kholil, 2010). At the beginning, the board consisted mostly of people of Arab descent who were disciples of Kiai Shaleh Darat. Within a year or so, their membership boasted 120 people (75 men, 45 women) (PB Moehammadijah, 1929:43).

From its foundation in 1912, the MM aimed to reform editorial and linguistic composition and terms and sought to promote Islam and spread the teachings of Prophet Muhammad (saw) among natives in the Yogyakarta region. After successfully expanding beyond Yogyakarta, with branches in several areas, the MM aimed to promote and encourage the teaching and learning of Islam throughout all of the Dutch East Indies and encourage daily living under Islamic principles (Pasha \& Darban, 2000:80-83).

To achieve these aims of renewal, promotional activities were tandemly developed for preaching, religion, education and social welfare. From its beginning the MSB established guidelines for preaching activities. Other programs included (a) establishing tabligh via schools and Aisiyah; (b) opening the Holands Inlandse Scholol (HIS) met de Qoer'an at the Muhammadiyah office in Poncol; (c) organizing a course for a board of committee, was hosted by Haji Fachruddin from Yogyakarta; (d) offering a Dutch language course; (e) building a library park, Hizboel Wathan and a General Adversary Helper; (f) Visitation to members, Arab leaders and other figures.

\subsection{Tabligh: The Early Strategy for Muhammadiyah Propagation}

Muhammadiyah is a movement of Islamic renewal that emphasizes the restoration of Islamic purity based on Qur'an and hadith. The MM persistently maintains that the door of ijtihad remains open and thus rejects the concept of taklid. Hence, ijtihad is an ongoing process for Muslims based on Qur'an and hadith whereby the MM offers fresh approaches to the implementation of $d a^{\prime} w a h$ and worship.

Tabligh is one of the movement's most prominent preaching activities. In period context, it is still fairly new, both in terms of form and content. Tabligh can be viewed as an intellectual approach that combines the 'common vergadering' of Sarekat Islam with the Christian missionary method; thus, they created a new preaching format. Tabligh meetings were usually held weekly after Isha prayers in the homes of members or in mosques, and were conducted by a Muhammadiyah preacher in Semarang. In its final 1926 report, the Board of Muhammadiyah East Indies reported that tabligh in Semarang was followed by number of participants, approximately 10-20 people. In addition, Tabligh meetings in Semarang were held in several places, including Petellan Kulon, Mertojoyo, Peterongan Kobong, Candi Karang Panas, Darat, Poncol, Pendrikan, Malang Pandean, and Randusari. (Pengoeroes Besar Moehammadijah Hindia Timoer, 1929: 138).

Another successful religious renewal effort included Muhammadiyah's pioneering work in the public sector, the one that birthed the women's movement called 'Aisiyah'. This association accompanied the establishment of the MSB in 1926 and clearly showed the movement's concern for the important positions of women in family, society and nation. A series of tabligh meetings was especially devoted to women, which pioneered Aisiyah. These events actually shifted the region's social perspective regarding women both domestically and publically. Aisiyah tabligh held in two region In Semarang four days in a week. First, Aisiyah tabligh held in Pedrikan on Wednesday, Friday, Saturday, and Sunday. Second, Aisiyah tabligh held in Darat on Tuesday, Wednesday, Thursday and Friday (Swara Islam, 1931 No. 2, p. 15).

Tabligh orientation sessions provided a general understanding of Islam. Participation was open to the public and the material presented was wide-ranging. The Semarang branch also broke new ground by organizing Islamic religious courses to better equip its membership with required skills for the proper performance of Islamic worship. In 1931, Swara Islam stated that MSB Islamic courses opened in the Pendrikan area and listed the curricula including reading Qur'an, Fiqih, Aqaid, Shalat (Swara Islam, 1931. No 2, p. 16). Such Islamic coursework was unique at the time because it provided religious material within the Tabligh's educational/preaching model, which was still very new and also rare. 


\subsection{Preaching Through Writing: Ancillary Analyses}

\subsubsection{The Modernization of Islamic Propagation}

In addition to formulated Islamic religious courses, preaching and teaching programs via tabligh, Muhammadiyah also advanced preaching by literature in Indonesia. Propagation by writing typified the MM use of books, magazines and leaflets, often distributed to government agencies, foreigners and the general public. Books published by Muhammadiyah up to 1927 included the following: Leader Sembahjang, Solatiel 'Ied, Aqaid Volume I, Feqih, Statuen Muhammadijah, Poestaka Tabligh I and II, Almanak 1346, Almanak Sobekan 1346, Shiratal Moestoqiem, Akaid Volume IV, Tarich Anbija', Tafsir Qoer'an, Poestaka Tabligh III, Feqih Volume III, Poedjian, Soerat Jasin, Keotoesnja Prophet Moehd, Islam and Teosophie, Sitti Aisjah, Talkin, Tafsir Kahfi, Tafsir Jasin, Tafsir Joes 30, Choetbah Djoem' Ah, 100 Hadith of the Prophet, and Food of the Brain. Magazines included: Soeara Moehammadijah, Soeara Aisjijah, Poestaka Hizboel Wathan, Soengoeting Moehammadijah Djawa, Mirah Moehammadijah Arab, Pepadang, Ampel Tower, Al Falah, Sjiar Islam, Al Chair, Annida, Soerja, and Koedoes Tower (Pengoeroes Besar Moehammadijah, 1929:15).

As a semi-autonomous institution under Muhammadiyah, Taman Poestaka managed Islamic preaching through literature and libraries during the early 1930s. MSB reading parks lent books on Islam in three places: Karangbalong, Karangasem Kampung Penaton No. 11 Darat, and Kampung Kuningan (Swara Islam, No. 2, 01Dec1931). The Semarang branch also published a magazine called Swara Islam in 1931 that was primarily used to disseminate the concept of Islamic renewal. They chose Javanese as its introductory language in order to reach Javanese readers. According to Thoha Hamim, this was only reformist magazine that used the Javanese language in Semarang (Hamim, 2000:57). Themes in this magazine were mostly directed towards theology, worship and ethics and often voiced puritan concepts to educate Muslims whose understanding of Islam was superficial. This appraoch is evident from columns on polemical issues that were presented in the form of munazarah (lessons as questions and answers) on Islamic moral standards, guidance for worship, and the foundations of belief in Allah and the Prophets.

The MSB's Taman Poestaka later issued a monthly magazine named Perhoeboengan, first published on 01 May 1940. Various rubrics were featured such as an editorial introduction, a Muhammadiyah room, a common room, a news room, and sundry columns and sections featuring correspondence and religious material. Compared to Swara Islam, Perhoeboengan displayed Islamic preaching in a far more general fashion and in simple language covering education, family and specifically women's issues (Perhoeboengan No 1/ I, 1940)

\subsubsection{Islamic Preaching with Social Charities}

Muhammadiyah, also known as the tajdid movement, was widely known for its charitable manifestations of Islamic renewal. Charities (Da'wah bi al hal) were essential to the Muhammadiyah spirit (Amin 2009:178; Editorial Board of The Islamic Encyclopedia 1994:282). The MM's charitable organizational arm was known as Amal Usaha and its pioneering work in various fields demonstrated astonishing degrees of social solidarity. These activities demonstrated that the movement's main Islamic mission actually implemented what they preached so that tajdid translated to an actual realization of a truly Islamic society by deed (Nashir 2010:393).

The movement's social charities naturally grew via participation by members and sympathizers, with depicted the true spirit of Islam as a way of living. Muhammadiyah's social charities met not only physical needs but also provided solutions to many problems faced by the community and individuals. An important agency that dealt with community issues head on was their Penolong Kesengsaraan Oemoem (PKO or General Misery Helper); a dedicated group that attended to the maintenance of both poor and orphans as well as the establishment of hospitals, the acceptance and distribution of zakat, and funerary services (Qa'idah Moehammadijah Bahagian Penolong Kesengsaraan Oemoem (PKO) Hindia Timoer di Djokjakarta, 1932: 5-7).

A serious contemporary problem involved innovative concepts concerning worship and studies in zakat. In Islam, zakat, besides being a holy directive, also commands the ummah to improve the welfare and social awareness of the less fortunate. Thus, Muhammadiyah deemed it needful to coordinate the implementation of zakat while also providing a fresh understanding of how to accept and share zakat. The MM subsequently and professionally upgraded the entire management of the zakat system in which funds had been previously collected and administered by very few people. In 1931, The MSB pioneered the development of PKO based in Pindrikan Ior and in 1932 Semarang's PKO Institute began its zakat fitrah management (Swara Islam, No. 4, 01Feb1932).

During Ramadan 1932, PKO maximized zakat fitrah collections from muzakki at seven postal stations in Semarang, (Karangbalong, East Semarang, Darat, Mertojoyo, Jalan Jeruk, Karangasem and Ibididaiyah School in Pindrikan Lor). PKO also coordinated the collection of zakat maal from Muhammadiyah members and the public. 
Zakat funds were then distributed to the needy-poor (Qa'idah Moehammadijah Bahagian Penolong Kesengsaraan Oemoem (PKO) Hindia Timoer di Djokjakarta, 1932:5-7).

In 1938, PKO MSB increased its services to the community by establishing orphanages and homes for the impoverished in Pendrikan Lor. These simple makeshift facilities housed orphans and sick people (Perhoeboengan, No. 2/I, 1940 and established the first Muhammadiyah orphanage in Semarang. PKO also held a mass circumcision ceremony on 14 July 1940 (Perhoeboengan, No. 3/I, 1940).

Muhammadiyah also developed an alternative education system. They were keen to produce a well-educated Muslim elite boasting a strong Islamic identity that was capable of guiding society by example, and could firmly face the many challenges presented by Western-educated secular elitists who governed and imposed the Dutch educational system (Jainuri 1990:44). The MM's system of educational reform combined old elements of the pesantren with new methodologies derived from Western educational systems.

This renewal of education was also a direct reaction to an overall qualitative decline in Islamic education. Muhammadiyah's educational reform of the pesantren system introduced a dualistic and innovative organizational and administrative approaches in addition to new curricula and course delivery systems. Borrowing from the colonial system, Muhammadiyah organized similar schools but added religious subjects to the curriculum (Abdurahman, 1990:120-121).

The MM's educational paradigm also birthed modern religious schools based on validated curricula, organization and administration. In addition to religious subjects, general subjects were taught including mathematics, geography, history and languages (Malay, Indonesian, Dutch, Latin letters and Arabic). The newly modelled school was called the madrasah (Daulay, 2001:59).

This fresh approach to management meant that lessons were given at the madrasah are no longer taught in mosques, but rather in specially dedicated school buildings where students sat on chairs or benches. Study time was organized and fixed on a daily schedule. Students were required to have textbooks and to be assessed by examinations for matriculation until graduation, after which they received a formal diploma. Schools of the madrasah model soon became another Muhammadiyah hallmark. The first Semarang madrasah model was established on 01 July 1927 in Pendrikan and named 'HIS met de Qur'an' (Hollandsch Inlandsche School), but was later called HIS Muhammadiyah. In its early days, HIS Muhammadiyah Semarang had a total of 39 students, 33 males and 6 females (Pengoeroes Besar Moehammadijah, 1929: 160)

Muhammadiyah Semarang also managed informal education. This is evident from English and Dutch courses given at HIS Muhammadiyah in Kp Gendingan, in addition to an English course held on 03 November 1931 in Kampung Kuningan, Darat. (Swara Islam, No. 2, p. 15, 01Dec1931). In addition, courses in Javanese and Latin were managed by Aisiyah. These activities provided educational opportunities for people who had never attended formal schooling (Swara Islam, No. 2, p. 21, 01Dec1931).

Thus, Muhammadiyah made ground-breaking breakthroughs by initiating a modern Islamic education system that integrated religious and general knowledge within a classical framework. Its modern system went on to birth a generation of Muslims with stronger faith, identities and knowledge firmly oriented towards progress and better enabled to face modern challenges. This new system integrated modern and religious sciences in a contemporary scheme that soon became the choice of the next Islamic generation, including traditional Islamic groups that had previously opposed Muhammadiyah's pioneering efforts.

\section{Conclusion}

Muhammadiyah's efforts in Semarang presented Islam as a strategically vibrant force in social charity, education, economics, health and social services that significantly empowered the community. Semarang's population, especially Muslims, were a backward lot of poverty stricken and socially marginalized minions. Civilization universally begins with the establishment of social and cultural institutions, especially those that meet physical needs in addition to spiritual requirements. Islamically, righteous charity is equated with faith and is extremely important. Hence, the MM's social charity work and general activities were always placed within a context that somehow practically enhanced the lives of Muslims and their community. The MM leadership considered Islamic preaching on its own an insufficient form of $d a^{\prime} w a h$ that cannot stop at theory or discourse but must become manifest by fruitful action.

Muhammadiyah's charitable efforts in health, social services and community empowerment had a broad influence that improved the quality of life and welfare of Muslims in particular, and society in general. Thus, the MM actually became a major pillar of Indonesian Islamic reform because it presented Islam as a realized solution for many problems faced by contemporary society. The movement's most valuable contribution was that it taught by 
example, so that Islam was not longer a basket of abstracted concepts filled with traditional dogma and heavenly doctrines, but rather a bountiful reality in the here and now.

This practical sway of Muhammadiyah amaliah strengthened the overall Muslim estate and protected them from untoward influences especially those of religions that traditionally exploited a people's backwardness for the purpose of spiritual and cultural proselytization. Muhammadiyah amaliah, according to Alwi Shihab's thesis, thus stemmed the tide of contemporary Christianization in Indonesia by competitively and objectively becoming a living buffer of Islamic endurance and success.

\section{Acknowledgments}

The authors would like to thank the MOE and University Technology of Malaysia (UTM), Research Management Centre (RMC), for $16 \mathrm{H} 48$ and $16 \mathrm{H} 72$ grants that have been supported this research.

\section{References}

Al-Qur'an dan Terjemahan. C.V. Toha Putra. Semarang.

Abdurahman, A. (1990). Muhammadiyah and Tajdid in the Field of Religion, Education and Society. In Al Islam and Muhammadiyah: Muhammadiyah: History, Thought and Charities. Yogyakarta: Tiara Wacana and UMM Press.

Amin, S. M. (2009). The Science of Da'wah. Jakarta: Amzah

Benda, H. J. (1980. The Crescent and The Rising Sun: Indonesian Islam during The Japanese Occupation, Jakarta: Pustaka Jaya.

Burhanudin, J. (2007). Mainstream Islam Indonesia. In Rizal Sukma and Clara Joewono (ed). Islamic Thought and Movement in Contemporary Indonesia, Jakarta: CSIS.

Daulay, H. P. (2001). Historicality and Existence of Pesantren, School and Madrasah, Yogyakarta: Tiara Wacana.

Deliar, N. (1996). The Modernist Muslim Movement in Indonesia. Jakarta: LP3ES.

Dhofier, Z. (1994). The Pesantren Tradition: A Study of the Role of the Kyai in the Maintenance of the Traditional Ideology of Islam in Java. Jakarta: LP3ES.

Editorial Board, The Islamic Encyclopedia. (1994). Jakarta: New Ichtiar van Hoeve.

Hamim, T. (2000). Paham Keagamaan Kaum Reformis. Yogyakarta: Tiara Wacana.

Interview with KH Ali Cholil (Grandson Kiai Saleh Darat, administrator of the Muhammadiyah Branch in Semarang, 1960s), May 2010.

Jainuri, A. (1990). Muhammadiyah as the Islamic Reform Movement. In M. Di Syamsudin (ed). Muhammadiyah Now and Tomorrow. Jakarta: Pustaka Panjimas.

Kuntowijoyo. (1999). Islamic Paradigm: An Interpretation for Action. Bandung: Mizan.

Nashir, H. (2010). Muhammadiyah: The Renewal Movement. Yogyakarta: Suara Muhammadiyah.

Nasikun. (1991). The Dilemma of Institutionalization of O 'Dea: Sociological Constraints on the Actualization of Religion. Paper presented at a seminar on Religion in Social Change, 11-12 March, Inter-University Social Studies Center, Universitas Gadjah Mada.

Pasha, M. K., \& Darban, A. A. (2000). Muhammadiyah as the Islamic Movement (Historical and Ideological Perspective). Yogyakarta: LPPI

Pengoeroes Besar Moehammadijah, Berita Tahoenan Moehammadijah Hindia Timoer Tahoen 1927 (Batavia: Landsdrukkerij, 1929).

Perhoeboengan, No. 1 (1940).

Perhoeboengan, No. 2 (1940).

Perhoeboengan, No. 3 (1940).

Qa'idah Moehammadijah Bahagian Penolong Kesengsaraan Oemoem (PKO) Hindia Timoer di Djokjakarta, 1932.

Shokheh, M. (2015). A New Response To The Challenge: Islamic Da'wah and Catholic Missions in Semarang, 1890s-1940s. Paramita, 25(2): 143-153.

Swara Islam, No 2, 1 December 1931.

Swara Islam, No. 4, 1 February 1932. 
Wertheim, W. F. (1999). Indonesian Society in Transition: A Study of Social Change. Yogyakarta: Tiara Wacana.

\section{Copyrights}

Copyright for this article is retained by the author(s), with first publication rights granted to the journal.

This is an open-access article distributed under the terms and conditions of the Creative Commons Attribution license (http://creativecommons.org/licenses/by/4.0/). 